\title{
Governance of Social Innovation in Forestry
}

\author{
Alice Ludvig ${ }^{1, *}{ }^{\mathbb{C}}$, Todora Rogelja ${ }^{2}$, Marelli Asamer-Handler ${ }^{3}$, Gerhard Weiss ${ }^{1}{ }^{1}$, \\ Maria Wilding ${ }^{4}$ and Ivana Zivojinovic ${ }^{1}$ (D)
}

1 Institute of Forest, Environmental and Natural Resource Policy and European Forest Institute-EFI Forest Policy Research Network, University of Natural Resources and Life Sciences, Vienna (BOKU), Feistmantelstraße 4, 1180 Vienna, Austria; gerhard.weiss@boku.ac.at (W.G.);

ivana.zivojinovic@boku.ac.at (Z.I.)

2 Department of Land, Environment, Agriculture and Forestry (TESAF), The University of Padova, Via dell'Università 16, 35020 Legnaro (PD), Italy; todora.rogelja@phd.unidp.it

3 ÖAR GmbH, Alberstrasse 10, 8010 Graz, Austria; asamer.handler@oear.at

4 Llais y Goedwig, Unit 6 Dyfi Eco Parc, Machynlleth, Powys SY20 8AX, Wales, UK; maria.wilding@llaisygoedwig.org.uk

* Correspondence: alice.ludvig@boku.ac.at; Tel.: +43-1-47654-73216

Received: 12 November 2019; Accepted: 31 January 2020; Published: 3 February 2020

check for updates

\begin{abstract}
Over the last decade, the term social innovation has received increased attention as a potential solution to address complex global social problems and to add collective values to society. The forest sector has great potential for fostering employment, community development and reducing increased emigration from rural to urban areas. This potential is not always realised, especially in economically weak and remote rural areas. Hence, this paper tackles the question of how social innovations in forestry are able to succeed under adverse circumstances and contribute to respond to some of the before mentioned challenges? To answer this question, we first identified three very different cases across Europe that are compatible with the criteria of social innovation. Proceeding from this starting point, comparative research was undertaken with the aim to identify the cases' specific features and key criteria for success. In the cases considered, it is evident that the sheer determination and voluntary investment of time and effort by key individuals, who were convinced of the value of the idea for the community, provided indispensable impetus to all three social innovations. In drawing its conclusions, this paper highlights the principal areas that need consideration and that hence have implications when developing supportive policies. Furthermore, we provide some insight into future research topics that would allow us to better understand the positive impacts of social innovation in the forest-based sector.
\end{abstract}

Keywords: forestry; forest sector; social entrepreneurship; forest ownership; collective action; cooperation

\section{Introduction}

Forests and woodlands in some parts of Europe form up to $50 \%$ of rural areas. To a greater or lesser extent, sustainable forestry and the sustainable use of forests are development factors for the vast majority of local rural communities. This was noted by the United Nations who combined it with the argument that local communities shall play a central role in the management of related resources [1]. Following on in the same vein, sustainable forestry has been identified in both the EU Biodiversity Strategy and the EU Forestry Strategy, as well as the latter's implementation plan, as one of the EU's top priorities [2] as it becomes increasingly apparent that there are new opportunities for the forestry sector to take a lead in the sustainable development of Europe's bioeconomy [3]. Innovations of all kinds, including social innovations, have a prominent role to play in the transformation to sustainable future forest use [4]. However, does the forest sector really partner well with social 
innovation? Indeed, forestry currently is often seen as a "mature" sector, somewhat low tech, or in worst-case scenarios as an industry in decline [5]. Nevertheless, the forest sector still contributes much to the quality of life and green economic development in rural areas. Modern forest products have gone beyond just timber to also include a range of ecosystem services such as recreation and tourism, biodiversity conservation and landscape amenities. Additionally, with the worlds growing awareness of environmental issues, forest's value in terms of $\mathrm{CO}_{2}$-storage, climate change mitigation and protective functions against natural hazards such as torrents or avalanches have come into sharp focus. In addition, a range of bio-based renewable products, including food, fibres and the products for sustainable wooden construction originate from forests. The recent boost with the use of social innovation has been brought about, at least in part, by both the fact the world currently seems to be lurching from one crisis to the next and the recognition of the complex societal problems communities around the globe are facing [6]. According to its most prominent proponents, theories on social innovation define it as a mechanism for civil society actors to find new ways to meet social needs and to fill gaps that are not being fulfilled by a state or market [7]. Thus, social innovation is sometimes seen as an alternative to policies and as a more bottom-up and flexible way to meet existing social needs. We understand that in difficult economic times and widespread crises in public social support systems that have resulted in drastic cuts to public spending, concepts such as social innovation are becoming increasingly attractive, even for the forest sector. However, social innovation cannot replace regular state-provided social services or rural development policies and there is a need for policies and formal institutions to support the emergence of social innovation processes.

In the forest sector, many of the ecosystem services provided by forests have little to no significant economic impact as they yield largely cultural and societal benefits or pertain to landscape maintenance, the combatting of air pollution and a variety of often free to use recreational services. All these services often have "public good" characteristics [8] and their production and marketing practices are frequently connected to landscapes as "territorial goods and services" $[9,10]$. This begs the necessity of exploring specifics to create income and employment opportunities in regions currently facing economic decline and the consequent land abandonment often seen from increased emigration. Hence, the goal of this paper is to explore the viability of the link between forestry and social innovation by asking: how can social innovation be developed in the forest sector. What are the main success features of the analysed social innovations? How can policies support social innovation?

The forest sector deems a relevant subject to empirical research in the area of social innovation [11] and because of its economic and cultural importance for many rural areas in Europe [2-4] it provides a most interesting example for the collection of evidence as well as a chance to broaden and expand the existing research findings [7].

In order to accomplish this, we use selected case study examples that are social innovations and stem from the forest based sector to extrapolate useful data.

The foregoing led us to the decision to study three cases of social innovation in three very different rural areas across Europe.

In the pages that follow we will first outline our theoretical approach to social innovation, volunteering and community engagement in forestry as a basis for the case studies and then introduce the methods applied in this research. The subsequent results section will draw its findings from a comparison of the three cases by analysing their differences and commonalities before finally discussing their nature from the perspective of their deductively derived criteria for social innovation: community activities, triggers, internal organisation, financing and support. Their different approaches to and solutions for these matters show the level of diversity in the governance of social innovation in forestry.

\section{Theoretical Background: Social Innovation and Forest Governance}

Our theoretical framework is built on actors-centred institutional theory [12,13] focusing on institutional government arrangements. Institutions are formed by rules and norms as well as actors and groups of actors [12,13]. Our conceptual notion of governance builds on the theories of 
non-hierarchical governance-processes [14,15], where especially non-state, private corporate and civil society actors participate and negotiate the formulation of public policy [16,17]. The theories on actors' involvement in governance assume that all cooperation between various actors takes place in different forms within mixed networks of public and private actors $[14,16,18]$. Linked to the theoretical background of social innovation, this implies for the conceptual basis of our research that precisely collective action allows social innovation to find innovative solutions to solve various pressing social, ecological and economic problems [19,20].

Following this, many of the greatest challenges facing both, social innovation and forest governance, have been connected to institutional issues and a lack of cooperation amongst actors [11,21]. Starting from definitions of social innovation for rural areas [22], engagement of civil society is conceptualised here as a necessary prerequisite. For this purpose, we apply the following definition developed by the SIMRA consortium which states that social innovation is "the reconfiguring of social practices, in response to societal challenges, which seeks to enhance outcomes on societal well-being and necessarily includes the engagement of civil society actors" [22] (p. 1). Hence, we understand social innovation as a broad process, encompassing the concepts of social entrepreneurship and social enterprise, but also a range of social initiatives and activities, which are socially innovative in the setting of the forest-based sector.

Hitting into this vein, it is specially the inclusion and participation in collective decision-making and action that have subsequent governance implications as it leads to novel coalitions of actors [23-25]. Thus, social innovation has a strong social orientation and addresses an unmet need, rather than being motivated by profit [19], although in some cases a social innovation may apply business practices to achieve its objectives [20]. Social innovation transforms social relations; in particular it can operate in an inclusive and empowering way, involving the participation of service users and deprived communities in governance $[18,20]$. This introduces a dimension of empowerment to social innovation: initiatives develop capacity and enhance capability by creating new collaborations and partnerships [14] which strengthen social assets and relationships [19].

In forestry, mutual arrangements and collective action, for example community forestry [26] can result in institutional changes also taking the form of altered actors' arrangements [27]. The inclusion of civil society leads to institutional change that tends to lead to the re-organisation of societal actors (forest owners, forest managers, consumers, producers) and their relationships [28]. The emphasis on changes in social practices and relationships is articulated in both social innovation literature $[6,19,22$, $29,30]$ as well as in governance literature $[12,15,16,23]$. Likewise, scholarly literature on institutional innovations [31,32] considers all changes in societal practices as important sources of institutional change. It is especially the systemic approaches in innovation literature that emphasise the interaction between actors and institutions as an important and central element [31]. New modes of forest governance go beyond the margins of the state, such as policy networks, public participation, active stakeholder inclusion, community forestry, markets for ecosystem services and public-private partnerships [3,8-11,21]. Social innovation comes into play when such new institutional arrangements are created in response to societal challenges with the inclusion of the local population and the goal of societal well being. When the innovation is not merely profit-driven, when multiple actors are involved in the creation of the innovation and are also affected by its outcome, the institutional innovations also fulfils the definition of being a social innovation $[22,33,34]$.

\section{Material and Methods}

\subsection{Case Study Methodology}

The aim of the paper is to better understand social innovation in the forest sector and to ask how social innovations in forestry are able to emerge and maintain themselves under adverse circumstances, such as those involving economically weak and remote rural areas? This will contribute to filling the existent gap in how the forest sector can profit from social innovation. To accomplish this, we first 
needed examples that fulfil the criteria of social innovation, especially innovations clearly demonstrating the collective engagement of mutual actors for the benefit of a broad group within civil society. We used two case study databases for our search: the "BOKU innovation case database" [35] and the "SIMRA case study database" [36]. Both databases are compiling innovation cases in forest-based and related sectors (e.g., forestry, rural development, agriculture, forest industry, education, etc.), with a total of 340 case study examples. Each case has its title, brief description and link to the webpage. These two databases originate from a few scientific projects (SIMRA, STARTREE, BeFoFu), in which selection of innovation cases for databases was done by project expert teams.

For the purpose of this research, from these two case databases, we first selected a sample of 11 cases that fit the search criteria: "Forestry/Forest sector/Forest-based bioeconomy" in combination with "Social innovation". From this pool of eleven cases, we identified the three best suited to our research question and that show the diversity of social innovation across forest activities and across European regions. The selection criteria were built on the conceptualization of social innovation and forest governance, in particular their civil society engagement as most prominent and specific feature. All three cases formed cooperative associations with strong involvement from civil society and produced collective benefits within the forest sector, thus featuring prominently governance aspects. Our cases include a "Charcoal Land Initiative" in Litija, Slovenia (SI), a community forestry enterprise in Wales (UK) and the "Nature Park Specialities" association in the Austrian region of Styria (AT). Furthermore, these three cases feature geographically distinct regions in Europe and also different products and activities, illustrating variety of institutional and natural conditions for developing social innovations. Case study as a research design for our purpose was best suited as case study is an "empirical inquiry that investigates a contemporary phenomenon within its real-life context" [37]. This approach was an ideal fit for this research as it allows us to look at contemporary social innovations in the forest sector that were acting as a mechanism for civil society actors to find new ways to meet social needs and to fill gaps that are not being fulfilled by state or markets [6,7]. As we are interested in how the forest sector can profit from social innovation, we first had to investigate into their features in-depth via qualitative research such as interviews. The descriptions in the databases are rather short and we needed to explore more into their genesis, their key features such as actors involved in order to derive the key governance features and success factors that led to their creation and maintenance [38].

\subsection{Data Collection and Analysis}

The primary data collection methods used in this research was qualitative semi-structured interviews with policy experts and practitioners from our chosen case examples, along with the search for relevant literature, web-based documents and additional background information about the cases (see Figure 1). Data was collected in two phases: 1) between July and December 2014-in the frame of the STARTREE project, this refers to the Welsh and the Austrian case, and 2) between July and December 2018 - in the frame of the SIMRA project for the Slovenian case. All data were collected by project partners in each region. Interview guidelines focusing on the innovation process, supporting/hindering factors in innovation process and institutional/policy conditions for developing innovations, in both projects were developed by the authors of this paper from BOKU University.

Since these cases arise from different projects, but all related to forestry innovations, from the obtained interviews we extracted information related to the aim of this paper. These are the essential criteria for aspects for the formation of social innovation in practice: trigger, needs, interactions, informative, financial, and cooperative support.

Hence, his article builds on a total of 35 semi-structured interviews carried out face-to-face with selected actors, such as the founders, producers, funding bodies, CEOs of consultancy agencies or other relevant personnel pertaining to three of the cases (see list of interview transcripts, Appendix A). The choice of the number of interviews and respondents was decided upon by the interviewers (mainly co-authors of this paper) and their decision was determined by the number of actors involved in each case, the willingness of the interviewees to give of their time and resources as well as the 
degree of information that was needed for each case in order to answer the research questions. Interviews lasted approximately one hour, were all recorded, and subsequently transcribed, with each hour of transcribed interview resulting in approximately 30 pages of text.

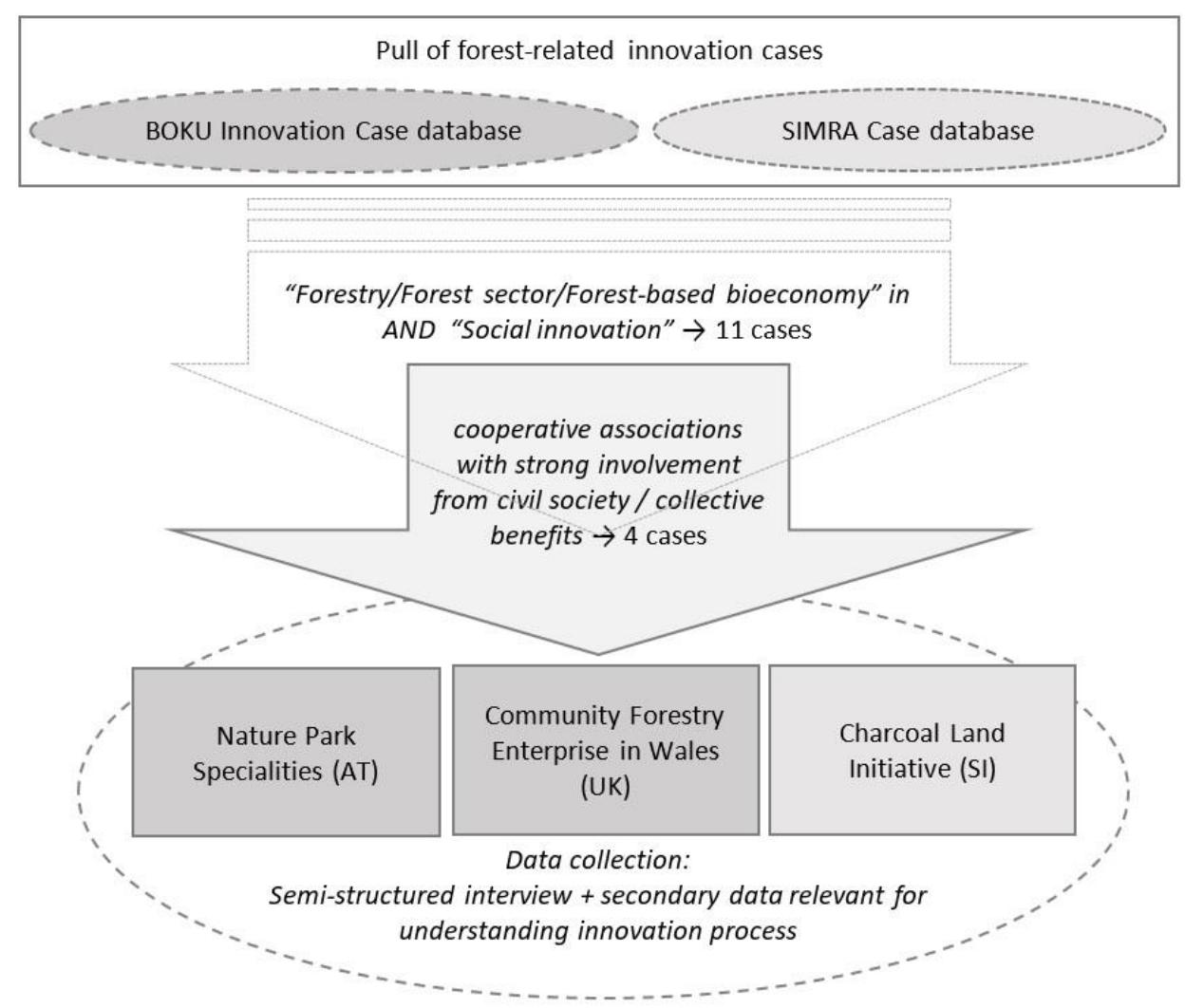

Figure 1. Data collection process for identifying social innovation in relation to forestry.

As secondary information for better understanding of the cases, we used available Internet sources or available documents related to case studies. Apart from semi-structured interviews related to innovation process itself, great understanding of the case conditions was provided in the already published material from SIMRA project (including authors of this paper) [33,34,39-41].

Our qualitative case study analysis is based on a mixture of deduction and induction: we took the theoretical assumptions from social innovation (the criteria for social innovation features [22-25]) and applied them to the cases in order to gain more theoretical insights, on the patterns and key features for success of social innovation in forestry, from the empirical material obtained. All the transcripts were analysed by applying qualitative content analysis [42]. In concrete terms, our analysis of the theoretical literature on innovation support enabled the initial identification of three key themes for the analysis, including (i) the triggers and motivations for starting the project, (ii) specific institutions and actors' involvement, (iv) and the three forms of support (informative, financial and cooperative). In order to address the important "pilot phase" in innovation processes, the interviews also investigated the specific genesis of each case, as outlined in the result section.

\section{Results}

This section presents our results of our case study analysis in terms of genesis of innovation processes, types, triggers, governance features and the main impacts at the institutional level. In particular, each case also mirrors the specific diversity of forest ecosystem services and products. It is striking, that the forest sector very often has been described as traditionally lacking when it comes to innovation [43]. If this is true, then it would follow that the same lethargy would likely be true 
for social innovation. Shakleton et al. [44] have already outlined in detail the difficulty of clearly identifying all the new forest (non-timber-) products and services because of their inherent variety and diversity. In result, our selection conforms to the scholarly standards for innovativeness [10] because the cases either introduce a new idea for a historical, traditional product (Slovenia) or commercialise a good or service in a new way that is unique for the sector and the region (UK, Austria) [45] (p.11) [46] (p.5). Moreover, all three cases characterise involvement of several actors and institutions that are supported by associations. Finally, one of them actively involves socially vulnerable groups in their training and skills development programme (UK).

In the Slovenian case, two district foresters had the idea of revitalising an economically weak area with collective charcoal burning activities which resulted in the creation of the "Charcoal Land Initiative" and sparked a revival of charcoal burning throughout Slovenia. The "Charcoal Land Initiative" is nowadays one of the main charcoal producers in Slovenia, being famous for its high quality, organic charcoal used mainly for barbecues. In the Austrian case, the recreational and cultural functions of the regional nature parks are complemented by the traditional products produced and provided by local farmers living in the parks and labelled as "Nature Park Specialties". Such products are primarily high quality "edible" specialities, such as jams, liquors, herbal teas or cosmetics, all produced in very small quantities and sold to hikers passing through the area as well as at fairs, in local pubs and in the various nature park "shops" in the area. In the Welsh case, a group of people leased a large parcel of land (the Cwm Plysgog woodland in Pembrokeshire) from its owner via a mutual agreement in order to establish a not-for-profit social enterprise called the "Coppicewood College" which is involved in woodland management and provides courses and training for the local public.

\subsection{The Charcoal Land Initiative in Slovenia}

This initiative led to new forms of associations at the national level. Charcoal burning in Slovenia was a 1000-year-old practice that was intensively undertaken until the Second World War (WWII) for solely economic reasons. After WWII, traditional charcoal burning decreased and by the 1980s had almost completely disappeared. In the late 1990s, a few charcoal burners from the village Dole pri Litiji (today part of the Charcoal Land Initiative) together with district forester (Mr J.P.) started reviving this old, traditional practice. It was Mr J.P. and Mr Z.K. who had the idea of initiating "Charcoal Land" and soon after, other actors joined. Individuals and organisational actors coming from the civil and public sectors were involved in the preparatory action (1999-2001) of the "Charcoal Land Initiative" which allowed it to grow from the two original innovators (Mr J.P. and Mr Z.K, individual actors), to 8 more partners (individual actors and organisations), and then finally to 30 partners (mostly organisations) by the year 2001. Those individuals and organisational actors supported the charcoal burning idea because as some said: "it was a good idea. J.P has many ideas, and although not all of them are good, most of them are. What is even more important, J.P. knows how to make them happen" (I_SSI7_INT-II-17 SLO). Although historically charcoal was burnt primarily in other parts of Slovenia, today (2018) most of the charcoal that is burnt is done in Dole pri Litiji. Every year about 16 charcoal burners in the "Charcoal Land Initiative" prepare about 30 charcoal piles, which in the summer of 2019 varied in size from 5-200 $\mathrm{m}^{3}$, and produce sufficient charcoal to meet the demand from the whole region. The initiative has diversified activities which include tourist and cultural activities (i.e., organising cultural or culinary events, hikes on charcoal paths or educational visits for pupils). The efforts and activities of the Charcoal Land Initiative have also had a positive impact on private forest owners with regard to the management of their forests [INT-II-17 SLO]. At the local level, the initiative created opportunities for new sources of income through charcoal sales and tourism development. At the national level, the interests of the charcoal burners are now represented by the Association of Slovenian Charcoal Burners that was established in August 2019. All these impacts cumulatively contributed to the image of a modern charcoal-burner as a craftsman or woman, teacher, practice carrier, engaged citizen and active private forest owner [INT-II-18 SLO]. 


\subsection{A Community Forestry Enterprise in Wales}

Community forestry is a type of bottom-up collective activity in the forest-based sector. Commonly owned forests and common property regimes are currently existing in many European countries, such as Austria, France, Italy, Romania, Slovenia, Spain and Switzerland [47]. The UK has emerged as a standout in this group, as there were several recent land reforms making it possible for privately organised groups to purchase land for so-called community forestry activities [48]. This has resulted in a whole range of different arrangements in terms of institutional structure [49] and we selected one not-for-profit community woodland registered as a "rural charity" that is a simple non-profit company which includes an additional associated enterprise of former trainees. The community forest enterprise in question has its focus in education, training and forestry services, relying on a few employees and involving trustees as well as a number of volunteers to accomplish this. Its name is "Coppicewood College" [50] (CWC) and it delivers training courses in woodland management skills at Cwm Plysgog woodland in Pembrokeshire, West Wales. Coppicing is an ancient craft involving cutting stems of broadleaved trees in rotation. It provides a varied canopy that encourages diversity in woodland flora and fauna, increasing the number of wild forest products available in a woodland. CWC also is a social enterprise as it provides specific course schemes for the long-term unemployed, delinquent youths, single mothers as well as elderly and handicapped citizens. Its main features are that it is first and foremost a strictly not-for-profit organisation; second, it is built on the basis of community engagement and flat hierarchies and third, it depends to a considerable extent on volunteer work. A final defining feature of CWC is that it is based on an agreement with the owner of the woodland, who lets the land for free to the group in return for a well-managed and preserved woodland. The main income source of CWC is the Ernest Cook Trust (TECT), one of the UK's leading educational charities, which specialises in conservation and countryside management. TECT allows grant applications to be submitted every three years and, since they started in 2006, CWC has made several successful applications. The courses they run are provided in agreement with several other charities as well as regional organisations and associations, such as the local scouts.

\subsection{Austria's "Nature Park Specialities" Association}

This initiative was founded by local farmers for revival of remote Austrian rural areas. By the governments definition, a nature park is a "cultural landscape" that has to fulfil three functions: (i) nature protection, (ii) provide recreational opportunities, (iii) education, and (iv) local development. Other than a "national park", this involved the people living in the area, including their activities and products. The majority of them are farmers. As such, the "Association of Austrian Nature Parks" (VNÖ) was founded in 1994 to incorporate 28 Austrian nature parks as members. Later on, others joined and today there are 46 such "nature parks" encompassing a total area of 500.000 ha. It turned out from our interviews, that first, a Christmas present "box" with locally produced food products from the parks was developed in 1999. Subsequently, all members agreed on a common label for these products. They acquired funding and consulted with an Austrian regional development consultancy company (ÖAR GmbH) that is still the managing executive that lobbies for the association and assists with applications for funding the project. According to our interviews, the idea came from several people in both the ÖAR and the VNÖ. The products include varieties of juices, teas, jams, liqueurs, wines, honey-based products, sweets, as well as meat and herb products. Some products stem from traditionally used domestic Austrian species (European pear, Pyrus communis, and blackthorn, Prunus spinose amongst others). Currently, all monetary support is acquired competitively through projects (partly via regional LEADER funding [51]). The organisations involved include the 20 Austrian nature parks that are active in the label, the umbrella organisation (VNÖ), the regional development consultancy company (ÖAR), and, in different aspects of the innovation, the Federal Ministry and the various federal state governments where the active nature parks are located. Its governance structure is diverse and up to changes, as not all parks are members and public policy is, due to unstable funding structures also not continuously involved. One of the interviewees from the ÖAR who was involved 
from the beginning gave the example of a nature park in Styria, "It was really so, that I was thinking 20 times, now what the hell, when they [the ministry] really do not want it, then we leave it. Eventually and suddenly they [the ministry] said, 'well ok, now we do it'" [52]. Between 2004-2006 and 2009-2012 the project received some LEADER [51] and EAFRD [53] funding via the abovementioned public authorities. However, because of the still bare-bones financial support, efforts to establish the label and promote it proved to be a difficult path and the organisation's future seemed uncertain many times.

The following table (Table 1) summarises the main results from this section. It illustrates the principal features, main types, governance features, main support base and main institutional/policy impacts for all cases.

It is important to note that all activities take place in localised areas where economic conditions are poor and local communities are suffering the aftermath of deteriorating or collapsed industrial production (AT, SI), are engaged in farming and forest management under increasingly difficult climatic conditions (AT), as well as often facing high rates of land abandonment, unemployment (SI, UK), and/or an ageing local population (AT). The cases we examined were sustainable or even flourished because of the continuous efforts of a range of various associations (UK), consulting firms (AT) and public administrations (SI) (Table 1, above). More specifically, in the Austrian case, larger associations were formed and professional consultancy agencies became involved. In terms of support, for the larger Austrian association, this came from a consulting firm (ÖAR) which helped with marketing and promotion aspects, with financial support coming from the public sector (e.g., LEADER support [45]), although this was difficult to obtain. The Slovenian case received support primarily from the active charcoal burners themselves, although the community and State Forest Service both had a positive view toward the activity and provided significant secondary support. Once the Charcoal Land Initiative had demonstrated its value the municipality came on board and the provincial administration began promoting it. The UK case received financial support from a small, but regular and flexible fund (TECT) in combination with strong cooperation from other associations and social enterprises which sent their clients to the training courses provided by Coppicewood College. Additionally, although no money changed hands, the mutual agreement with the owner of the land who freely let his land to the group in return for a well-managed and preserved woodland, made the project both financially viable and brought many benefits to the local region and communities. 
Table 1. Results: Types, triggers, governance features and main impact at institutional policy level of three social innovations in the forest sector (elaborated by the authors).

\begin{tabular}{|c|c|c|c|c|c|c|}
\hline Name & $\begin{array}{l}\text { Social Innovation } \\
\text { Features }\end{array}$ & $\begin{array}{l}\text { Type of Activity in } \\
\text { Forest Sector }\end{array}$ & Key Initial Triggers & $\begin{array}{l}\text { Main (Financial) } \\
\text { Support }\end{array}$ & $\begin{array}{l}\text { New Governance } \\
\text { Structures and New } \\
\text { Actors Roles }\end{array}$ & $\begin{array}{c}\text { Main Impact at } \\
\text { Institutional/Policy Level }\end{array}$ \\
\hline $\begin{array}{l}\text { The Charcoal } \\
\text { Land Initiative } \\
\text { (SI) }\end{array}$ & $\begin{array}{c}\text { Volunteer collective } \\
\text { engagement, } \\
\text { historical innovation }\end{array}$ & $\begin{array}{l}\text { Non-wood forest } \\
\text { product }\end{array}$ & $\begin{array}{ll}\text { - } & \text { Regional } \\
\text { - } & \text { An initiative of } \\
\text { two local actors } \\
\text { - } & \text { Revival of } \\
\text { interest in } \\
\text { charcoal burning }\end{array}$ & $\begin{array}{ll} & \\
\text { on } & \\
\text { - } & \text { Volunteer work } \\
\text { - } & \text { Income from } \\
& \text { selling charcoal }\end{array}$ & $\begin{array}{ll}\text { - } & \text { Formation of new } \\
\text { network/ initiative } \\
\text { - } & \text { Formation of } \\
\text { Association on } \\
\text { national level }\end{array}$ & $\begin{array}{l}\text { - Broadened forest policy } \\
\text { perspective (via creation } \\
\text { of new } \\
\text { interests/revived products) } \\
\text { - Activation of private } \\
\text { forest owners in } \\
\text { this activity }\end{array}$ \\
\hline $\begin{array}{l}\text { Coppicewood } \\
\text { College in Wales } \\
\text { (UK) }\end{array}$ & $\begin{array}{l}\text { Volunteer collective } \\
\text { engagement, regional } \\
\text { innovation }\end{array}$ & $\begin{array}{l}\text { Non-wood forest } \\
\text { product and } \\
\text { ecosystem services }\end{array}$ & $\begin{array}{ll}\text { - } & \text { New land } \\
\text { reform opened } \\
\text { up opportunities } \\
\text { - An initiative by } \\
\text { a group of locals }\end{array}$ & $\begin{array}{ll}\text { - } & \text { Volunteer work } \\
\text { - } & \text { Income } \\
\text { from courses } \\
\text { - } & \text { Grant funding } \\
& (\mathrm{TECT})\end{array}$ & $\begin{array}{l}\text { - Community forest } \\
\text { enterprise become } \\
\text { main actor } \\
\text { (bottom-up) }\end{array}$ & $\begin{array}{l}\text { - Community engagement } \\
\text { in forest management }\end{array}$ \\
\hline $\begin{array}{l}\text { Austrian Nature } \\
\text { Park Specialties } \\
\text { (AT) }\end{array}$ & $\begin{array}{l}\text { Volunteer collective } \\
\text { engagement, market } \\
\text { innovation }\end{array}$ & $\begin{array}{l}\text { Non-wood forest } \\
\text { product and } \\
\text { ecosystem services }\end{array}$ & $\begin{array}{l}\text { - Foundation of } \\
\text { nature } \\
\text { parks beforehand } \\
\text { The need to } \\
\text { market the } \\
\text { products from } \\
\text { the nature parks }\end{array}$ & 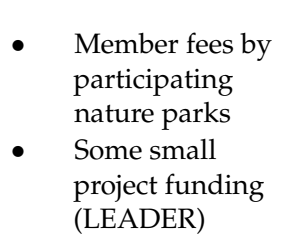 & $\begin{array}{ll}\text { - } & \text { Involvement of } \\
\text { consultancy agency } \\
\text { - Active bottom-up } \\
\text { role of local } \\
\text { producers enhanced. }\end{array}$ & $\begin{array}{l}\text { Establishment of a label } \\
\text { and novel } \\
\text { marketing concept. }\end{array}$ \\
\hline
\end{tabular}


In all three cases, being able to secure volunteers to work is one of the most important features. Volunteer work was especially important during the founding phase in all three cases, and it still has an indispensable role in the UK case. Indeed, CWC's success is due to a combination of a large amount of volunteer work from its founders and other volunteers together with the flexible grant funding. Furthermore, they needed the clear terms in the mutual agreement with the landowner in order to initially secure the use of the site. Indeed, it is unlikely CWC would still exist without the particular type of funding they have been fortunate enough to receive. If the organisers had only been able to access the more prescriptive kind of funding grants that are more typically available, this would have significantly hindered, or possibly prematurely ended, the activities of the college. For those responsible for designing future funding criteria, this is almost certainly the most important lesson to be learned from this particular case. CWC is a small business which has no plans to expand, as evidenced by the fact that it has existed in its present form for almost 12 years. The interviewees for this case expressed the desire that "it should be judged on its positive impact on the surrounding human and natural environments" [INT-1, UK]. When viewed in this way, the CWC can and should be viewed as a success story and is a credit to those involved. With its green ethos it has always strived to have positive environmental impact on its surroundings and this has clearly been the case. CWC provides a prime example to other local woodland owners of just what is possible to do with their own properties if they have the will. The college has been instrumental in developing the social forestry sector in Wales and is a showcase for how to successfully combine addressing social needs with training in the forestry sector.

The initial ideas originated from specific individuals (innovators) who had the will to turn their ideas into reality. Some were subsequently supported either by a consulting agency (such as the ÖAR in Austria) or by regular funding (TECT funding in the UK case). The charcoal case in Slovenia simply relied upon the strong enthusiasm of the local population and the charisma of its initiators (Mr J.P. and Mr Z.K). It received no direct funding but in-kind financing and support from public organisations (i.e., State Forest Service). Unlike "Nature Park Specialities", the Charcoal Land Initiative is not a "label" in the commercial sense as is it is neither registered nor protected. The interviews with the charcoal burners showed a strong personal identification and connection with the project. When we asked "what does the Charcoal Land Initiative mean for them", they answered that it is what they do and are. "[ ... ] here, what you see, it is a charcoal land, it is our area, but it is also what we do and who we are." [I_SLO-KII 2].

\section{Discussion: Governance of Social Innovation in Forestry}

Ros-Tonen and Kusters [54] have emphasised the importance of functional institutional frameworks as decisive factors in determining the success (or failure) of the use of forest-based products in cases of developing countries. In particular, we have observed in the three considered cases from the forest sector (i) strong agency, (ii) creative and novel related impacts on their social innovation endeavours $[8,9,19,23,25]$. The cases (iii) underline the importance of partnerships and participatory action for this process and different funding strategies [41]. This way, our examination of cases reveals several governance aspects as outlined in our theoretical framework above [12,13,24,25]. Such are especially the (i) cooperation and collective action features found in the cases. These features are bottom-up in their nature and refer to all non-hierarchical processes outlined in governance literature [14-17]. However, the findings expand our theoretical assumptions by adding deeper insights into (ii) regional peculiarities and new evidence on (iii) distinct policy features as additional institutional features.

(i) Cooperation and collective action: In each of these cases, the gradual formation of an organised structure and establishing cooperative networks was no coincidence. Each developmental step was necessary to build capacity, as no single entrepreneur, forest owner or manager could have achieved the desired outcome alone. Initially, all of the cases involved small-scale collaboration and cooperation where a few key individuals invested time and effort in an idea because they 
believed there would be a benefit for the local community, including themselves. The relationships that develop are, at least initially, largely based on trust.

(ii) Regional peculiarities: The second point of note is that three of the cases have a regional marketing strategy in common that refers to the specific regional landscapes (the Austrian Nature Parks), regions (The Charcoal Land Initiative in Slovenia), or woodland as a specific forest type (Coppicewood College in Western Wales). Their brands and methods of regional marketing also attract consumers from outside their immediate respective areas. All of these cases are embedded in their broader regional areas and involve a larger network of individuals than are directly involved as each brand, label or service offered requires various cooperative interactions from numerous partner groups. These characteristics are what render these innovations as social innovations; they are characterised by repeated practices and institutional formations.

(iii) Distinct policy features: A third aspect worth considering with the researched cases is that there were some additional institutional features supporting them, such as formal institutions, policies or organisations, which are all external in character. The Austrian case could avail itself of some LEADER and EAFRD funds, albeit under rather difficult circumstances, and the UK-case has one main financial source in the TECT fund, which according to the interviewees has proven to be extremely convenient as it provides flexible funding and a relatively reliable income stream. Yet, its key influential institutional factor was the Land Reforms act of 2006 which made it possible for groups to acquire and manage land for community forest purposes. The Charcoal Land Initiative relies on the income it derives from selling its charcoal, but especially in the initial phase, its sustainability was predicated on the volunteer work by those members of the community directly involved and by support from the municipalities.

One of the advocates of the concept of social innovation has formulated briefly that social innovation can be seen as 'new ideas that address unmet social needs-and that works' [29]. The examples examined by this research all demonstrate how their activities are carried out in very unique ways and with markedly different methods. Because of the nature of social innovation as a non-market based innovation [22], it is not the primary goal to measure the success of such ventures in terms of economic turnover or employee numbers. An example are the Austrian "Nature Park Specialities" developed with the efforts of the regional consultancy agency even though the products are moderately limited in range and cannot be mass-produced (which is not the association's intention anyway). Indeed, it is an interesting aspect of this case that it is not the products alone which have created the benefits arising from this particular social innovation, but rather their combination with the rest of the concept of "nature parks" in Austria, which includes the landscape, culture, interaction with locals and the recreational assets in the region that have created a positive synergy. Such practical implications of our findings call for a focus on support of regionally adapted policy solutions that are able to maintain and strengthen territorial capital as well as natural and socio-economic benefits.

\section{Conclusions}

Social innovation functions as a mechanism for civil society actors to find new ways to meet social needs and to fill gaps that are not being fulfilled by the state or markets [30]. Many of the ecosystem services provided by forests have no directly marketable benefit as many have their roots in cultural and societal values rather than economics, typical examples being landscape maintenance, combating of air pollution and a wide variety of free to use recreational services. All proponents of the cases in the present study wanted to do something and change a specific (sometimes economic) situation to improve an often dire local situation and open up new opportunities for the communities in which they lived.

These examples from forestry prove that social innovation often develops out of a specific need or set of circumstances and does not follow the normal developmental path of regular business models from the start. The example of CWC (UK) demonstrates for instance, how even a small amount of well-targeted funding can have an immense impact on an innovative organisation. In the case of CWC, 
the fact that this funding was so flexible allowed it to be readily tailored to the specific needs and allowed the social innovation a near-optimal financial environment to establish itself and flourish.

The cases for social innovation considered above are service-based and include strong societal and social aspects. They either involve a broader range of actors and stakeholders other than just the actual producers and initiators, or they have strong inclusive features and target larger groups and communities. Furthermore, they cover a broad range of goods and services in the forest bioeconomy which include intangible features beyond a mere focus on the production of timber [55]. They also include "softer" outcomes, such as ensuring social stability or strengthening community bonds and identity via collective action and the creation of at least some income in the more remote rural areas where the frequently operate. There are often multiple actors involved in creative innovation, and these are also affected by its outcome as it develops into a social innovation. The decisive point for being a social innovation is the quality and degree of the social aspects of the innovations' impacts as well as the quality and degree of the inclusion of civil society actors that are involved.

In conclusion then, the role that activities such as woodland management and forestry play in rural and regional development is unquestionably important. One reason for this is that woodlands are frequently found in increasingly disadvantaged rural areas where options for employment and income are limited and the utilisation of forest resources can help address these issues. From a policy perspective, social innovation in forestry can be fostered by various means, including the financial support of forest owners' cooperatives and governmental cooperation along the value chains, innovative processes, business development, marketing instruments and with regional or rural development initiatives. Arguably, the most important step is the "preparation of the ground", meaning investments in creating opportunity, be that via education, cultural activities or opening doors via legislation. Social innovations add value in many ways and at many levels in rural communities which, among other benefits, serves to combat the growing problem of land abandonment currently plaguing Europe's rural areas. Such policy instruments need to better connect to bottom-up projects for regional economic, societal and cultural proliferation as top-down measures alone have often proven to be inefficient or ineffective [56]. Gaining access to meaningful advice, funding and networks are factors that are highly likely to act as "innovation accelerators". Such support functions may take many forms and be provided through NGOs [57], producer associations, cluster organisations or regional and rural development programmes. Whichever approach to support is settled upon their needs to be a room for manoeuver, flexibility and the ability to create customised opportunity structures that are as unique as the respective regions they serve. For future research this means that the following topics have to be more closely examined and better understood: the types of support needed for innovation in forestry, especially for all the up-scaling stages as being better established increases both the robustness and sustainability of innovation. A second key area of concern is the specific need of better operational management for service innovations. This brings special attention to the examples for collectively conducted combined innovations examined in this article.

Author Contributions: A.L. undertook the work in overall research design, case selection and was the lead writer on the paper, A.L., I.Z., T.R.; M.W. and M.A.-H. contributed to case study research, fieldwork, documentation and interpretation. All authors have read and agreed to the published version of the manuscript.

Funding: This research received funding under the Horizon 2020 project SIMRA (Social Innovation in Marginalized Rural Areas) under Grant Agreement No. 677622 from the European Commission. The text's publication was supported by BOKU Vienna's Open Access Publishing Fund.

Acknowledgments: We thank all our interview partners for giving so freely of their time and effort to assist with this research.

Conflicts of Interest: The authors declare that no conflict of interest exists. 


\section{Appendix A}

Table A1. List of interview transcripts (All interviewees agreed with the anonymization of their personal names according to ethical standards but did not want the specific names of their organisations to be rendered anonymous).

\begin{tabular}{l} 
List of interview transcripts \\
\hline INT I AUT22092014 (ÖAR, referee) \\
INT II AUT23092014 (ÖAR, CEO) \\
INT II AUT22092014 (VNÖ) \\
INT I UK October 2014, Principal founder of Coppicewood College \\
INT II UK October 2014, owner of land \\
INT III UK November 2014, interview with a representative of Coed Lleol, a woodland development \\
organisation with a Wales-wide scope. \\
INT I SLO The lead researcher for this case conducted 5 different interviews with the key informant (KII 1-5) \\
during the first half of 2018. The interviews lasted from $1-4$ hours and were recorded and transcribed. In the \\
first interview, the key informant told the overall story of the Charcoal Land initiative and the reconfiguration \\
of the charcoal burning practice. The second conversation focused on the identification of crucial events, while \\
the following three conversations then went into detail in each event, a description of a situation, and the \\
identification of involved actors and their roles. \\
INT II to INTXX SLO During 2018 until the first half of 2019,20 semi-structured interviews in the duration of \\
30 to 90 minutes were conducted with participants in the initiative, other local stakeholders and regional \\
politicians.
\end{tabular}

\section{References}

1. SDG. Life on Land. Available online: https://www.undp.org/content/undp/en/home/sustainabledevelopment-goals/goal-15-life-on-land.html (accessed on 31 December 2019).

2. European Commission. Forestry Explained. Available online: https://ec.europa.eu/info/food-farmingfisheries/forestry/forestry-explained\# (accessed on 31 December 2019).

3. Wolfslehner, B.; Linser, S.; Pülzl, H.; Bastrup-Birk, A.; Camia, A.; Marchetti, M. Forest bioeconomy-A new scope for sustainability indicators. Available online: https:/www.ieabioenergy.com/wp-content/uploads/ 2018/01/efi_fstp_4_2016.pdf (accessed on 31 December 2019).

4. Sarkki, S.; Parpan, T.; Melnykovych, M.; Zahvoyska, L.; Derbal, J.; Voloshyna, N.; Nijnik, M. Beyond participation! Social innovations facilitating movement from authoritative state to participatory forest governance in Ukraine. Landsc. Ecol. 2019, 34, 1601-1618. [CrossRef]

5. Weiss, G. The Study of Innovation in the Forest Sector: Relevance and Research Background. Available online: https://www.cabi.org/bookshop/book/9781845936891/ (accessed on 31 December 2019).

6. Dias, J.; Partidário, M. Mind the Gap: The Potential Transformative Capacity of Social Innovation. Available online: https://www.researchgate.net/publication/335237022_Mind_the_Gap_The_Potential_Transformative_ Capacity_of_Social_Innovation (accessed on 31 December 2019).

7. Moulaert, F.; Martinelli, F.; Gonzalez, S.; Swyngedouw, E. Introduction: Social Innovation and Governance in European Cities: Urban Development between Path Dependency and Radical Innovation. Eur. Urban Reg. Stud. 2007, 14, 195-209. [CrossRef]

8. Mavsar, R.; Ramcilovic, S.; Palahi, M. Study on the Development and Marketing of Non-Market Forest Products and Services. Available online: https:/ec.europa.eu/agriculture/external-studies/forest-products_en (accessed on 31 December 2019).

9. Slee, B. Innovation in Forest-related Territorial Goods and Services: An Introduction. Available online: https://www.researchgate.net/publication/288077578_Innovation_in_forest-related_territorial_goods_and_ services_An_introduction (accessed on 31 December 2019).

10. Weiss, G. Theoretical approaches for the analysis of innovation processes and policies in the forest sector. Available online: https://www.researchgate.net/publication/286940598_Theoretical_approaches_for_the_ analysis_of_innovation_processes_and_policies_in_the_forest_sector (accessed on 31 December 2019). 
11. Secco, L.; Pisani, E.; Da Re, R.; Rogelja, T.; Burlando, C.; Vicentini, K.; Pettenella, D.; Masiero, M.; Miller, D.; Nijnik, M. Towards a method of evaluating social innovation in forest-dependent rural communities: First suggestions from a science-stakeholder collaboration. Forest Policy Econ. 2019, 104, 9-22. [CrossRef]

12. Ostrom, E. Understanding Institutional Diversity; Princeton University Press: Princeton, NJ, USA, 2005.

13. Ostrom, E. Background on the institutional analysis and development framework. Policy. Stud. J. 2011, 39, 7-27. [CrossRef]

14. Ostrom, E. Governing the Commons: The Evolution Of Institutions For Collective Action; Cambridge University Press: New York, NY, USA, 1990.

15. Mayntz, R.; Scharpf, F.W. Steuerung und Selbstorganisation in staatsnahen Sektoren. Available online: https: //pure.mpg.de/pubman/faces/ViewItemOverviewPage.jsp?itemId=item_1235772 (accessed on 31 December 2019).

16. Mayntz, R. New Challenges to Governance Theory. Jean Monet Chair Papers No. 50; European University Institute: Florence, Italy, 1998.

17. Rhodes, R.A. Understanding Governance. Policy Networks, Governance, Reflexivity and Accountability; Open University Press: Buckingham, PA, USA, 1997.

18. Mayntz, R. From government to governance: Political steering in modern societies. Govern. Integrat. Prod. Policy 2003, 9, 18-25.

19. Sinclair, S.; Baglioni, S. Social Innovation and Social Policy - Promises and Risks. Soc. Policy Soc. 2014, 13, 469-476. [CrossRef]

20. Mulgan, G. The Process of Social Innovation. Innov. Technol. Gov. Glob. 2006, 1, 145-162. [CrossRef]

21. Weiss, G.; Salka, J.; Dobsinska, Z.; Aggestam, F.; Tykkä, S.; Bauer, A.; Rametsteiner, E. Integrating Innovation in Forest and Development Policies: Comparative Analysis of National Policies across Europe. Available online: https://www.researchgate.net/publication/303684723_Forest_Policy_Integration_in_Europe_ Lessons_Learnt_Challenges_Ahead_and_Strategies_to_Support_Sustainable_Forest_Management_and_ Multifunctional_Forestry_in_the_Future (accessed on 31 December 2019).

22. Polman, N.; Slee, W.; Kluvánková, T.; Dijkshoorn, M.; Nijnik, M.; Gezik, V.; Soma, K. Classification of Social Innovations for Marginalized Rural Areas. Available online: https:/research.wur.nl/en/publications/ classification-of-social-innovations-for-marginalized-rural-areas (accessed on 31 December 2019).

23. Feiock, R.C. Institutional Collective Action and Local Governance. Available online: https://digitalcommons. wayne.edu/cgi/viewcontent.cgi?article=1004\&context=interlocal_coop (accessed on 31 December 2019).

24. Rhodes, R.A. Understanding Governance: Ten Years On. Organ. Stud. 2007, 28, 1243-1264. [CrossRef]

25. Rhodes, R.A.; Binder, S.; Rockman, B.A. The Oxford Handbook of Political Institutions; Oxford University Press: Oxford, UK, 2008.

26. Ludvig, A.; Wilding, M.; Thorogood, A.; Gerhard, W.T. Social innovation in the Welsh Woodlands: Community based forestry as collective third-sector engagement. Policy Econ. 2018, 95, 18-25. [CrossRef]

27. Rogelja, T.; Ludvig, A.; Weiss, G.; Secco, L. Implications of policy framework conditions for the development of forestry-based social innovation initiatives in Slovenia. Policy Econ. 2018, 95, 147-155. [CrossRef]

28. Abson, D.J.; Fischer, J.; Leventon, J. Leverage points for sustainability transformation. Ambio 2017, 46, 30-43. [CrossRef] [PubMed]

29. Mulgan, G. The Theoretical Foundations of Social Innovation. In Social Innovation; Nicholls, A., Murdock, A., Eds.; Palgrave Macmillan: London, UK, 2012; pp. 33-65.

30. Murray, R.; Caulier-Grice, J.; Mulgan, G. The Open Book of Social Innovation; NESTA, Innovating Public Services, The Young Foundation: London, UK, 2010.

31. Edquist, C.; Johnson, B. Institutions and Organizations in Systems of Innovations. Available online: https://www. researchgate.net/publication/270450284_Institutions_and_Organisations_in_Systems_of_Innovation (accessed on 31 December 2019).

32. Ruttan, V.W. Social science knowledge and induced institutional innovation: an institutional design perspective. J. Inst. Econ. 2006, 2, 249-272. [CrossRef] 
33. Ludvig, A.; Weiss, G.; Živojinović, I.; Nijnik, M.; Miller, D.; Barlagne, C.; Perlik, M.; Hermann, P.; Egger, T.; Dalla Torre, C.; et al. Report D6.1: Political Framework Conditions, Policies and Instruments for SIs in Rural Areas. Social Innovation in Marginalised Rural Areas (SIMRA). Available online: http://www.simra-h2020. eu/index.php/deliverables/ (accessed on 3 February 2020).

34. Ludvig, A.; Weiss, G.; Živojinović, I.; Nijnik, M.; Miller, D.; Barlagne, C.; Dijkshoorn-Dekker, M.; Jack, S.; Al Khaled, S.; Polman, N.; et al. Report D6.2: Policy Implications for Social Innovation in Marginalised Rural Areas. Social Innovation in Marginalised Rural Areas (SIMRA). Available online: http://www.simra-h2020. eu/index.php/deliverables/ (accessed on 3 February 2020).

35. Valero, D. Social Innovations in Marginalised Rural Areas. Available online: http://www.simra-h2020.eu/ index.php/simradatabase/ (accessed on 10 November 2019).

36. Weiss, G. Policy Database Boku University. Available online: http://policydatabase.boku.ac.at/ (accessed on 10 November 2019).

37. Yin, R. Case Study Research, Design and Methods, Thousand Oaks and London; SAGE Publications: Thousand Oaks, CA, USA, 2009.

38. Lijphart, A. Comparative Politics and the Comparative Method. Am. Polit. Sci. Rev. 1971, 65, $682-693$. [CrossRef]

39. Górriz-Mifsud, E.; Burns, M.; Marini Govigli, V. Civil society engaged in wildfires: Mediterranean forest fire volunteer groupings. For. Policy Econ. 2019, 102, 119-129. [CrossRef]

40. Bryce, R.; Valero, D.; Price, M. Creation of Interactive Database of Examples of Social Innovation, Deliverable 3.2, Social Innovation in Marginalised Rural Areas (SIMRA). Available online: http://www.simra-h2020.eu/ index.php/deliverables/ (accessed on 3 February 2020).

41. Goórriz-Mifsud, E.; Govigli, V.M.; Ravazzoli, E.; Dalla Torre, C.; Da Re, R.; Secco, L.; Pisani, E.; Ludvig, A.; Weiss, G.; Kluvánková, T. Training Material for Data Collection at CS Level. SIMRA Deliverable 5.2, Social Innovation in Marginalised Rural Areas (SIMRA). Available online: http://www.simra-h2020.eu/index.php/ deliverables/ (accessed on 3 February 2020).

42. Mayring, P. Qualitative Inhaltsanalyse. Grundlagen und Techniken; Beltz Verlag: Weinheim, Germany; Basel, Switzerland, 2000.

43. Hansen, E.; Nybakk, E.; Panwar, R. Innovation insights from North American forest sector research: A literature review. Forests 2014, 5, 1341-1355. [CrossRef]

44. Shackleton, C.; Delang, C.O.; Shackleton, S.; Shanley, P. Non-timber Forest Products: Concepts and Definitions; Springer: Berlin/Heidelberg, Germany, 2011.

45. Edquist, C. Systems of Innovation Approaches: Their Emergence And Characteristics; Technologies, Institutions and Organizations: London, UK, 1997.

46. Nelson, R.; Rosenberg, N. Technical Innovation and National Systems; Oxford University Press: Oxford, UK, 1993.

47. Živojinović, I.; Weiss, G.; Lidestav, G.; Feliciano, D.; Hujala, T.; Dobšinská, Z.; Lawrence, A.; Nybakk, E.; Quiroga, S.; Schraml, U. Forest Land Ownership Change in Europe; University of Natural Resources and Life Sciences: Vienna, Austria, 2015.

48. Lawrence, A.; Anglezarke, B.; Frost, B.; Nolan, P.; Owen, R. What does community forestry mean in a devolved Great Britain? Int. For. Rev. 2009, 11, 281-297. [CrossRef]

49. Ambrose-Oji, B.; Lawrence, A.; Stewart, A. Community based forest enterprise in Britain: Two organising typologies. For. Pol. Econ. 2014, 58, 65-74. [CrossRef]

50. Coppice Wood College. Applying Traditional Rural Skills to Modern Life. Available online: http:// coppicewoodcollege.co.uk/ (accessed on 9 October 2019).

51. European Network for Rural Development. LEADER/CLLD. Available online: https://enrd.ec.europa.eu/ leader-clld_en (accessed on 6 November 2019).

52. Translation by author M A.H from German interview transcript: „Es war echt so, dass ich dazwischen schon 20-mal gemeint hab, jetzt was solls-wenn sie nicht wollen, dann sollen sie es bleiben lassen. Irgendwann haben sie dann plötzlich gesagt, na ok jetzt machen wir es doch so." (INT I AUT220914, p9) \#00:26:13-2\#.

53. European Agricultural Fund for Rural Development. Available online: https://eur-lex.europa.eu/legalcontent/EN/TXT/HTML/?uri=LEGISSUM:160032\&from=EN (accessed on 3 February 2020).

54. Ros-Tonen, M.; Kusters, K. Pro-Poor Governance of Non-Timber Forest Products: The Need for Secure Tenure, the Rule of Law, Market Access and Partnerships; Springer: Berlin, Germany, 2011. 
55. Laakkonen, A.; Hujala, T.; Pykäläinen, J. Integrating intangible resources enables creating new types of forest services - developing forest leasing value network in Finland. Forest Policy Econom. 2018, 99, 157-168. [CrossRef]

56. Weiss, G.; Ludvig, A.; Zivojinovic, I.; Asamer-Handler, M.; Huber, P. Non-timber innovations: How to innovate in side-activities of forestry. Austrian Sci. 2017, 134, 231-250.

57. Živojinović, I.; Ludvig, A.; Hogl, K. Social Innovation to Sustain Rural Communities: Overcoming Institutional Challenges in Serbia. Sustainability 2019, 11, 7248. [CrossRef]

(C) 2020 by the authors. Licensee MDPI, Basel, Switzerland. This article is an open access article distributed under the terms and conditions of the Creative Commons Attribution (CC BY) license (http://creativecommons.org/licenses/by/4.0/). 